it should be fairly easy for those entirely ignorant of Russian to understand the results and methods of the papers.

\section{Belgian Visitors to Britain}

THE fourth group of distinguished Belgians to visit Great Britain as representatives of the Belgian Fondation Universitaire and guests of the British Council have arrived in London. They are: Prof. M. Florkin, Faculty of Science and Medicine, Liège ; Prof. F. Albert, Faculty of Medicine, University of Liège ; Prof. F. Bremer, Faculty of Medicine, University of Brussels ; Prof. A. Castille, Faculty of Medicine, Louvain ; Prof. J. C. Firket, Faculty of Medicine, Liège ; Prof. H. R. Frederica, Faculty of Medicine, Liège; M. Jean Willems, director of the National Fund for Scientific Research (see p. 780); and Prof. L. M. Gyselynck, Faculty of Law, Brussels. They are meeting leading British authorities in their particular spheres in universities and research institutions in London, Cambridge, Oxford, Liverpool, Edinburgh, Glasgow and Belfast.

\section{University of London}

Prof. D. Hughes Parry, University professor of English law at the London School of Economics and a member of the Senate since 1930, has been elected vice-chancellor for the year 1945-46.

The title of professor emeritus has been conferred on the following: Prof. Major Greenwood, professor of epidemiology and vital statistics since 1926; Prof. William Wilson, Hildred Carlile professor of physics at Bedford College from 1921 until his retirement in 1944 ; Prof. Harold Simpson, professor of mathematics at Bedford College from 1912 until his retirement in 1944.

Prof. C. Daryll Forde, since 1930 Gregynog professor of geography and anthropology at University College, Aberystwyth, has been appointed to the University chair of anthropology tenable at University College as from October 1, 1945 .

The degree of D.Sc. has been conferred on Ur. E. T. Davies (Birkbeck College), Dr. F. W. Jane (Birkbeck College), Mr. S. G. Soal (Queen Mary College), Mr. A. C. Frazer (St. Mary's Hospital Medical School), Mr. L. A. Allen and Mr. C. G. Johnson.

\section{Summer School in Colloid Science}

The Birmingham and Midlands Section of the Royal Institute of Chemistry has arranged, in co-operation with the Departments of Colloid Science and Physical Chemistry of the University of Cambridge, a Summer School in Colloid. Science in the form of two courses, extending from June 23 to June 30 and June 30 to July 7 respectively. The director of tuition for the School is Dr. A. E. Alexander. Both courses are being opened by Prof. E. K. Rideal, professor of colloid science in the University of Cambridge and president of the Society of Chemical Industry, and the opening lectures are by Dr. W. Clayton, on "Foods as Colloid Systems" (course A), and Dr. E. H. Callow, on "Colloids in Theory and Practice" (course B). Some two hundred research chemists are attending the School.

\section{The Night Sky in July}

NEw moon occurs on July 9d. 13h. 35m., U.T., and full moon on July 25d. 02h. $25 \mathrm{~m}$. The following conjunctions with the moon take place: July 5d. 06h., Mars $3^{\circ}$ N. ; July 6d. 02h., Venus $0 \cdot 4^{\circ}$ N. ; July 11d. 10h., Mercury $2^{\circ}$ S.; July 14d. 12h., Jupiter $4^{\circ} \mathrm{S}$. Only one occultation takes place in July, 20 Ceti reappearing on July 30 d. $00 \mathrm{~h}$. $37 \cdot 7 \mathrm{~m}$. ; the time refers to the latitude of Greenwich. Mercury sets at $21 \mathrm{~h} .26 \mathrm{~m}$., and $20 \mathrm{~h}$. $22 \mathrm{~m}$. at the beginning and end of the month respectively, attaining its greatest easterly elongation on July 23, and is not very well placed for observation during the month. Venus is a conspicuous object in the early morning hours, rising at $1 \mathrm{~h} .30 \mathrm{~m}$. and $1 \mathrm{~h} .08 \mathrm{~m}$. at the beginning and end of the month respectively. Mars moves from the constellation of Aries into Taurus during July and rises at $0 \mathrm{~h} .53 \mathrm{~m}$. on July 1 and $23 \mathrm{~h}$. $18 \mathrm{~m}$. on July 31. Jupiter sets at $23 \mathrm{~h} .15 \mathrm{~m}$. at the beginning of the month and at $21 \mathrm{~h} .27 \mathrm{~m}$. on July 31 , about an hour and a half after sunset, and is not easily observed. Saturn sets about quarter of an hour before the sun on July 1 and is not favourably placed for observation. The earth is at aphelion on July 5 .

A total eclipse of the sun takes place on July 9, partly visible as a partial eclipse at Greenwich, where the eclipse begins at $12 \mathrm{~h} .45 \mathrm{~m}$. and ends at $15 \mathrm{~h} .11 \mathrm{~m}$. The magnitude of the eclipse at Greenwich is 0.61 . The central line commences in long. $115^{\circ} 57^{\prime} \mathrm{W}$. and lat. $44^{\circ} 23^{\prime} \mathrm{N}$., and ends in long. $72^{\circ} 33^{\prime} \mathrm{E}$., and lat. $41^{\circ} 43^{\prime} \mathrm{N}$.

\section{Announcements}

Prof. Arnold N. ShImmin, now acting professor of industrial relations in the University of Leeds, has been appointed to the newly instituted chair of social science in the Department of Economics of the University.

Dr. Kathleen Lonsdale has been appointed by the managers of the Royal Institution to be Dewar Research Fellow in succession to Dr. A. R. Ubbelohde.

The Committee of Privy Council for the Organisation and Development of Agricultural Research has appointed Prof. T. G. B. Osborn, Dr. J. L. Simonsen, and Mr. W. J. Wright as members of the Agricultural Research Council in succession to Prof. E. J. Salisbury, Sir Robert Robertson and Sir Robert Greig, whose terms of office as members of the Council have expired.

The Library of the Chemical Society is now re maining open for longer hours; it is open from 10 a.m. to 6 p.m. on Mondays to Fridays and 10 a.m. to 5 p.m. on Saturdays.

The fifth number of the Revre d'Alger published by the University of Algiers includes an interpretation of the American constitution, under the title "The Function of the President of the United States", by A. Heekscher, an article by G. Darmois on "The Tercentenary of the Birth of Newton with an Appreciation of his Work" ; and one by J. Malmejac and S. Cruck on "Penicillin : History of a Recent Discovery in Medical Therapy". G. Cohen contributes a note on the Free School of High Studies at New York, urging the creation in Paris of a similar school for American students living in France, and M. Koch a survey of the French Rhine and its economic and imperial role.

ERRATUM.--In his communication on "Calculation of the Results of Microbiological Assays" in Nature of May 26, Mr. Eric C. Woods states that on p. 633, line 11, "2 $\mu \mathrm{gm}$." should read " $0 \cdot 1 \mu \mathrm{gm} . "$. 